\title{
RURAL WOMEN ENTREPRENEUR AND CAPACITY BUILDING: ROLE OF NGOS IN EMPOWERING WOMEN IN INDIA
}

\author{
Dr.P.Maduraiveeran ${ }^{1}$, Dr. G.P.Sudha ${ }^{2}$ \\ ${ }^{1}$ Professor, Anna Centre for Public Affairs, University of Madras, Chennai - 600 005, India \\ ${ }^{2}$ Guest faculty, Anna Centre for Public Affairs, University of Madras, Chennai - 600 005, India
}

\section{Introduction}

After the Second World War participation of women in industrial and service sector has increased due to evident need for producing more and providing services. In developed countries, the numbers of self employed women have also phenomenally increased. It is true that women were most attached with kids, kitchen and knitting. This was replaced by powder, pappad and pickles. In due course of time women became both small and medium entrepreneurs. However, women have been facing lot of challenges and barriers. As far as India is concerned, women in rural areas had been confined themselves to small business and micro level or cottage industries found in the village side. Majority of rural women entrepreneurs are concentrated in low-paid, low-skilled and low-productivity jobs. They have basic indigenous knowledge, skill and potential to establish and manage enterprises.

"Any rural woman or group of rural women who innovates, imitates or adopts an economic activity may be referred as a rural women entrepreneur. Similarly an adult women who creates, who owns and runs an enterprise in rural area can be defined as rural women entrepreneur."

As far as India is concerned, women's participation in trade, industry and commerce, requiring entrepreneurship is still not up to mark because of the various problems and stigma associated with their gender roles. Thus promotion of entrepreneurship and economic empowerment of women pose a challenge to the government funding agencies and non-governmental organizations. Dealing with government agencies, knowing the government regulations, and the taxations, time management, balancing life and family ,negotiating skills, networking and stress management skills are necessary for them.

Some of the issues challenging the women entrepreneurs particularly rural area are shortage of finances, limited mobility, male dominance, lack of education, performing motherly duties and lack of achievement motivation.3 Another important finding is [Rizvi and Gupta, (2009)], that government sponsored entrepreneur development activities have benefited only a small section of urban middle class women because of their level of education, access to information and their family support.

Despite a new work culture and increased participation of women in workforce, women in entrepreneurial roles are very limited. The probable reason may be their conflicts between competing work demands, personal and family needs. However, entrepreneurship 
provides more opportunities for self employment more income and enhanced economic status to the rural women.

Along with the women empowerment processes, development of entrepreneurship, training of women as entrepreneur, capacity building for women entrepreneurs and bank linkages and inculcating skill training have also simultaneously taking place. It is in this context the research entitled "Rural Women Entrepreneurs and Capacity Building: Role of Non-Governmental Organizations in Empowering Women in India" has been undertaken.

\section{Limitation of the study}

This study mainly emphasizes the role of non-governmental organizations in empowering women in rural areas of Villupuram district of Tamilnadu, India for understanding the crucial role of nongovernmental organizations. Three nongovernmental organizations from Villupuram district, particularly which are providing capacity building, training to women entrepreneurs have been chosen. They are :

1. Auroville Village Action Group (AVAG)

2. Community Action for Rural Development Society (CARDS)

3. Rural Education Action For Liberation (REAL)

According to World Bank, investing more in business of women rather in men leads to greater development of a nation. Empowering women in entrepreneurship leads to break the inequalities and reduces poverty. The government has realized the importance of women entrepreneurship. As a result, it offers a variety of programmes for women entrepreneurs. Such entrepreneurs are helped by Tamil Nadu Corporation for Development of Women, which in turn are implemented by various non- governmental organizations

\section{Objective of the study}

The main objective of the study is to analyze the role of non- governmental organizations engaged in capacity building activities for women entrepreneurs in Villupuram district of Tamilnadu.

1. To study the socio-economic background of the rural women entrepreneurs and their interest in entrepreneurship.

2. To enumerate the various strategies adopted by non- governmental organizations for empowering women through entrepreneurship.

3. To analyse the adequacy of training and capacity building activities undertaken by nongovernmental organizations particularly for women entrepreneurship.

4. To suggest various measures for improving the rural women enterprisesEquations should be centred and should be numbered with the number on the right-hand side.

\subsection{Challenges Faced by Rural Women Entrepreneurs}

1. Personal Challenges

2. Social Challenges

3. Financial Challenges

4. Marketing Challenges

5. Managerial Challenges

6. Technological Challenges

7. Skill Challenges 


\subsection{Problems faced by Women Entrepreneur}

1. Capability training

2. Finding new customers because of instability of demand

3. Obtaining financing

4. Dealing with the employee problems

5. Product pricing

6. Planning for market expansion

7. Handling legal problems

8. Determining and maintaining product quality

9. Collaborating agency

10. Diversification and decentralization

11. Women entrepreneurs needs differ

A strong desire to do something positive is an inbuilt quality of women entrepreneur who are capable in contributing values in both family and social life. With the advent of media especially digital media, women have become more aware about their trades, rights and also working culture. The opportunities and challenges available to women in the digital era has made them job providers instead of jobseekers by becoming women entrepreneurs. They are capable of becoming innovative and produce more new products. They can establish their own identity and status in society. They can economically support their family and become role models for others.

They are been motivated by success stories, of friends and peer groups. Through their economic empowerment they create future for their wards. They also are supported by government through subsidy, bank loans and marketing guidance, etc. They become economically independent and generate more employment for others. Moreover, the new challenges and opportunities provide them self - esteem and self- fulfillment.

It is found that majority 56 per cent of the rural women entrepreneur are in the age group of 40-50. More than 90 percent women are married and nearly half of the rural women have more than secondary grade and many of them are graduates. Education remains the most important factor - to get loan, to understand the dynamics of entrepreneurship, manufacturing and marketing process, human resources, etc.,

More than 60 per cent rural women entrepreneurs face financial challenges.

\section{Conclusion}

Development of women Entrepreneurship particularly in rural areas is an indication of social transformation and breaking of traditional taboos. The capacity building programmes provided by non- governmental organizations have transformed the middle class women into innovative, hardworking, achievable women entrepreneur. Though the nongovernmental organizations and governmental support is limited in many ways but play a crucial role in empowering women in rural areas.

Another important barrier to women entrepreneur is geographical locations and the availability of raw materials and marketing opportunities particularly in rural areas and for rural women entrepreneur it is a big challenge. They may find raw material and produce a lot of goods and services but they would not find marketing agencies. Here the nongovernmental organizations help the rural women entrepreneurs to locate marketing opportunities for their products, services because the non- governmental organizations operates at national and international level or they can use their networking power beyond the geographical location. For instance the coconut shell products produced in Kerala are 
marketed in the time square of New York through non- governmental organizations supported online marketing with eco friendly leveling.

Yet another most valuable input provided by non- governmental organizations is introduction of innovative techniques and providing technical knowhow from international collaborating agencies to illustrate several dry fishing women entrepreneurs uses solar technology in coastal areas of Kanyakumari and Gujarat - with the help of international non- governmental organizations. Similarly, preservation and food processing women entrepreneurs use such solar heaters for their entrepreneurship in Villupuram district in cashew nut processing, export industries which provide considerable foreign exchange

\section{Suggestions}

Women who underwent some type of entrepreneurial training must given another chance when particular women or group want to switch over to a new avenue or diversification of their enterprises to produce new products and services. Non- governmental organizations found in the Villupuram district have identified a number of new entrepreneurial ventures for women entrepreneurs mobilized by Self Help Groups.

Among the rural entrepreneurs technology adoptions secure to be very minimal despite several training and awareness programme use of internet and e-commerce as well as online transactions are not encouraging therefore further emphasize must be made into this area for digitally empowering entrepreneurship among rural women. Branding, common branding of the products of the entrepreneurs promoted by the SHGs still remain a unfinished task because through geographically women entrepreneurs were federated among themselves wither they produce different products based on the availability of raw materials in their area. Therefore, common branding still remains an issue. Rural women entrepreneur are not able to compete with mega malls and multinational companies, in the range of products, investment and exhibiting their products in a mega malls and halls, public relations activities, etc.,

The number of women entrepreneur is growing. Research has identified that woman entrepreneur are less likely to grow. Women entrepreneurs face a wide variety of challenges both in starting and developing their business ventures. Considering these challenges, entrepreneurial advising, and training and education services found to play a positive role in venture success.

It is true that needs of entrepreneur service/care needs differ based upon the enterprises and the entrepreneurial stage. But the government gives training on a monotonous manner here non- governmental organizations differ and provide selective and needed training to bridge the gap between existing and expected needs of the entrepreneurs.

\section{References}

1. R. Sivanesan, Int. J. Res. Manag. Bus. Stud. (2014)

2. Ibid.

3. D. K. VYAS, C. P. PATEL, F. H. SHAH, and M. S. BHATT, An Int. Peer Rev. Multidiscip. Res. J. 19 (2006)

4. P. Adinarayana Reddy, Women Work Particip. Status Train. Oppor. (2011)

5. Jhunjhunwala and M. Jhunjhunwala, Indian Approach to Women's Empowerment (International Specialized Book Service Incorporated, 2004)

6. A. Prasad, Women Empowerment and Globalisation: A Modern Perspective (Swastik Publications, 2012) 